\title{
Parenting Program in Growing Parents' Positive Parenting at PAUD Al-Ummah Deli Tua
}

\author{
Munisa \\ Faculty of Islamic Studies and Humanities, Universitas Pembangunan Panca Budi Medan, Indonesia \\ munisa@pancabudi.ac.id
}

\begin{abstract}
Parenting is the basis for the child to shape his/her personality. One of the impacts of parenting will be seen when the child is in the school environment. Children's problems at school cannot be removed from parenting at home. The success of children in both academic and non-academic schools is also supported by the pattern of parenting that children receive in the family environment. Therefore, the education carried out in the school should synergize with the education carried out in the family. Parenting behavior towards the child often shows impatience, incapable of self-control, complaining when facing parenting difficulties and not listening to the child's problems attentively. This devotion aims to know the effectiveness of programs to positively improve parenting skills through Mindful parenting programs. Mindful parenting can be interpreted as parental awareness in paying attention, aiming and not labeling or negative assessment of each child's experience. Based on the above, it is necessary to do activities to address the problem through the devotion of parenting programs in fostering positive parenting behavior in Paud Al Ummah delitua.
\end{abstract}

Keywords early childhood, positive parenting, parents

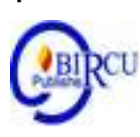

\section{Introduction}

As the process of growth and development, a child will go through stages of development with different development tasks, the success of achieving a developmental task at one stage will help smooth the next stage (Febrianti, Yus and Yusnadi, 2020). Parenting is the basis for children in shaping their personality (Smith, 2002). One of the impacts of parenting will be seen when the child is in the school environment. Children's problems at school cannot be separated from the care of parents at home. The success of children in school, both academically and non-academically, is also supported by the parenting patterns that children receive in the family environment. Therefore, education carried out in schools should work in synergy with education carried out in families. The importance of the role of parents in the context of education in order to prevent and minimize children's behavior problems needs attention. This is very important so that parents have knowledge of correct parenting and are able to solve problems and assist their children's growth and development properly.

Parenting behavior towards children who are in adolescence often shows impatience, is unable to control themselves, complains when facing parenting difficulties and does not listen to children's problems attentively. So that to determine the effectiveness of the program in improving parenting skills positively through the mindful parenting program. Mindful parenting can be interpreted as parental awareness in paying attention, aiming and not giving negative labels or assessments of every child's experience (Duncan, 2015: 256). Mindful parenting skills are fundamental for parents in carrying out interactions with 
children. Parents who have mindful parenting skills will avoid the stress caused by parenting (parenting stress), be able to respect children's opinions and actions, be able to carry out the role of parents, and establish a harmonious relationship between parent and child. Meanwhile, children will feel appreciated, the problems faced can be communicated properly to parents. Parents' mindful parenting skills will encourage children to do the expected behavior positively and consistently in preventing problematic behavior and developing a positive family atmosphere (Bluth \& Wahler, 2011).

Based on data in the field, one parent stated that the experience of parents in caring for children shows that parents feel a burden in terms of caring for children, are very troublesome, and require a large amount of time, causing unpleasant or uncomfortable feelings for parents. This is manifested in the experience of parents who are sometimes impatient with children, unable to control themselves, and not being tolerant.

According to Sanders (1999: 72), the causes of problems for parents around childcare include negative parental attribution of children's behavior, low anger control in parents, and lack of parental knowledge about childcare so that they experience difficulties and have an impact on the parent-child relationship. Astuti et al (2019) state that development of children's mental health is needed to be done since early. According to Steinberg (2000), negative parenting is caused by several things, including poverty, mental instability of parents, lack of social support for families and a wrong understanding of parenting. For example, the assumption that corporal punishment isthe best way to enforce discipline. Coie and Dodge (1998) state that parenting errors are inseparable from factors that influence parenting behavior, namely culture, personality patterns, attitudes towards parenting (authoritarian, permissive, democratic) and parental figure modeling.

\section{Review of Literatures}

\subsection{Early Childhood}

\section{a. Definition of Early Childhood}

Early childhood is a group of people aged 0-6 years. As for based on child education experts, namely groups of people aged 6-8 years. Early childhood is a group of children who are in a unique process of growth and development, in the sense that they have a pattern of growth and development (fine and gross motor coordination), intelligence (thinking power, creativity, emotional intelligence and spiritual intelligence), social emotional (attitudes and behavior as well as religion), language and communication specifically in accordance with the level of growth and development of children (Hurlock, 2014).

According to Mulyasa (2012) early age is a period of development and growth that is very decisive for children in their future or also called the golden age as well as a very critical period that determines the stage of growth and development of the next child. Early childhood is a golden opportunity for children to learn. Therefore, this opportunity should be used as well as possible for children's learning because the curiosity of children this age is at the top. In the golden age, there is a tremendous transformation in the brain and body, so that this age is very important for the intellectual, spiritual, emotional, and social development of children according to their respective characteristics. Therefore, education and the right environment to develop children at an early age are needed. According to Sugiharto (2020) Education is one of the efforts to improve the ability of human intelligence, thus he is able to improve the quality of his life. So, to create the highest quality of human resources, education is becoming an important factor to be considered. 
From the above statement it can be concluded that early childhood is a group of people aged $0-8$ years.

\section{b. Characteristics of Early Childhood}

According to Mukti Amini (2008) early childhood has several characters, including:

1. Have a great curiosity

Early childhood has a great curiosity. Everything around him wanted him to know. Then, the child also starts to like asking questions even though in very simple language. Usually with the word "what" or "why". Therefore, every question needs to be served with a wise and comprehensive answer, and not just an answer. In fact, we can also stimulate children's curiosity by asking questions back to the child.

2. Unique personality

Although twins, each child must have their own uniqueness such as learning styles, interests, and family backgrounds. In this uniqueness can come from genetic factors or come from the child's environment.

3. Like to fantasize and imagine

According to Lubis, fantasy is the ability to form new responses with the help of existing responses. Meanwhile, according to books by father and mother, imagination is that early childhood likes to imagine and develop various things far beyond the real conditions. Meanwhile, the child's ability to create an object without the support of real data. Children's fantasies and imagination are very important for development. Therefore, fantasy and imagination need to be directed and developed through various activities.

4. The most potential period for learning

The golden age is the golden age, which is a term used for early childhood. Because in this age range children experience very rapid growth and development in various aspects. According to Siskandar, positive and constructive relationships in early childhood are very important for cognitive development and social emotions. Therefore, early childhood is the most sensitive and potential period to learn something. Educators need to provide appropriate stimulation to these children.

5. Shows egocentric attitude

According to Hurlock, early childhood generally only understands things from their own point of view, not from others. Egocentic children think and talk more about themselves than about other people who aim to benefit themselves. This can be seen from the child's behavior, for example, likes to grab his friend's toys, annoy his friends, etc.

6. Has a short concentration span

Early childhood has a short attention span so that the child's attention is diverted to other activities. Age 5 years to be able to sit quietly and then pay attention to something is about 10 minutes, except for things that make him happy, according to Berg's explanation. Therefore, an educator needs to create a pleasant atmosphere in educating them.

7. As part of a social being

Through social interaction with peers, for example by hanging out, playing with friends, learning to share, giving in, etc., early childhood will form their self-concept. The child also learns to socialize and learn to be accepted in his environment. In this case, of course, the child will learn to behave according to his social expectations because the child needs other people in his life. Therefore, as an educator, he needs to direct his child to behave socially well. 
Based on the description above, it can be concluded that the characteristics of early childhood are having a great curiosity, a unique personality, like to fantasize and imagine, the most potential period for learning, shows an egocentric attitude, has a short concentration span, and is part of a social being.

\subsection{Positive Parenting}

a. Definition of Positive Parenting

Positive caregivers are closely related to the ability of a family / household and community to provide attention, time and support to meet the physical, mental and social needs of children who are growing and for other family members (Engel et al. 1997). . Hoghughi (2004) states that parenting includes a variety of activities aimed at making children develop optimally and survive well. The principle of parenting according to Hoghughi does not emphasize who (the perpetrator) but rather emphasizes the activities of children's development and education. Therefore, care includes physical care, emotional care and social care.

Social care is very important because the social relationships that are built in parenting will form a perspective on himself and his environment. Good social care focuses on providing assistance to children to be well integrated in their home and school environment and helping teach children about responsibility social must be carried out (Hughoghi, 2004).

A developmental psychologist defines parenting as a series of decisions about outreach to children, which includes what parents / caregivers should do so that the child is able to be responsible and contribute as a member of society including what parents / caregivers should do when the child is crying, angry, lying, and not doing their duties properly (Berns, 1997). Berns (1997) states that parenting is a process of interaction that takes place continuously and affects not only children but also parents. In line with Berns, Brooks (2001) also defines parenting as a process that refers to a series of actions and interactions taken by parents to support children's development. The parenting process is not a one-way relationship in which parents influence children but more than that, parenting is a process of interaction between parents and children that is influenced by the culture and social institutions in which the child is raised.

According to Yuliati Iswandiari (in https://hellosehat.com/parenting/tipsparenting/pengasuhan-positif-parenting/\#gref) Positive parenting is a pattern of parenting that is carried out in a supportive, constructive, and fun way. Supportive means providing treatment that supports children's development, constructive means being positive by avoiding violence or punishment, and doing it in a fun way. With positive parenting, it can improve the quality of children's interactions with parents, optimize children's growth and development, and prevent deviant behaviors (Erliyanti, 2012).

According to the Ministry of Education and Culture (https://sahabatkeluarga.kemdikbud.go.id/laman/uploads/Dokumen/3995_20160824/Buku $\% 20 \mathrm{Saku} \% 20 \mathrm{Pengasuhan} \% 20 \mathrm{Positif}-\mathrm{edLina}$.pdf), the main principles of positive parenting are as follows:

1. Children should be treated with respect, free from violence, and with love and affection.

2. Providing a safe, comfortable, and friendly environment for children's growth and development. 


\section{b. The Role of Parents in Shaping Children's Prosocial Behavior}

The family is the first and foremost center of education, according to Ki Hajar Dewantara. Children really need special attention from their parents. This is because parents have to teach their children the aspects of good association with people in the house, friends and the surrounding community. The child must receive guidance in their social behavior just like at home, parents must also provide education about their hobby of working and like helping their parents work at home (Suharyanto, 2015). Levine emphasized that the personality of the parents will affect the way the parents educate and raise their children, which in turn will also affect the child's personality.

According to Hurlock, the goal of parenting is to educate children so that children can adjust to their social environment and be accepted by society. The place where a child interacting for the first time is a family environment. In the family environment, a person also receives teachings and education from his parents, so that indirectly the family will influence the child's prosocial behavior. Family plays an important role in shaping the character and traits of children which will later influence proposial behavior in children. Besides parents as the main educators, parents also have another role is to pay attention to each child from various aspects, namely school, health, food, learning and play activities, etc. Regarding the formation of prosocial behavior, parents ideally can give more time to pay attention to their family. If these parents can provide quality time for the family, then the parents can also pay special attention and provide the right example for their children. At least, if parents work outside the home, parents can balance the time between working outside the home and paying attention to their children.

\section{Research Method}

The approach method used in the implementation of community service is lectures and questions and answers. The lecture material was presented through slides to the participants followed by questions and answers. Implementation of the service program which was held on March 2, 2020 at Paud Al-Ummah Delitua. The work procedures carried out in this community service are as follows: conducting field observations to the community, presenting lectures on positive parenting to students' parents, discussions and questions and answers with participants, closing and group photos.

\section{Result and Discussion}

\subsection{Result}

The parenting program in fostering positive parenting behavior for parents was held on March 2, 2020 at the Al-Ummah Deli Tua PAUD at 10:00 WIB. In this outreach activity, about 20 participants were present who were parents of students at PAUD AlHikmah Deli Tua. This counseling went well and it was seen that the participants were enthusiastic because this was something new for them so the information obtained was very useful.

Observations indicate that some parents think that parenting should only be done by the mother. Then the care that has been given by the parents is believed to have had a positive impact on the child, even though by scolding or even hitting their child. There are still many parents who are not aware of what positive parenting is and how to apply it.

Based on the expert opinion of Duncan, et al. (2009, p. 589) describes 5 dimensions of Mindful parenting, namely listening attentively; acceptance of not inspiring oneself and children; self and child emotional awareness; self-regulation in parenting relationships; and 
compassion for yourself and children. And parents still lack understanding of the meaning of positive parenting. So that this effective positive parenting program can increase parents' awareness of positive parenting and how to apply it in the family.

\subsection{Discussion}

The counseling which was held on March 2, 2020 at the Al-Ummah Deli Tua PAUD at 10:00 WIB went smoothly and well. Parents are given time to understand what is conveyed by flashback of what they did to their children. This counseling is carried out based on data obtained from the teacher that there are still many parenting behaviors towards children, often showing impatience, unable to control themselves, complaining when facing parenting difficulties and not listening to children's problems attentively.

There are several things parents can do to gain awareness about positive parenting, namely:

a. Listen attentively

Mindfulness is an essential aspect of effective parenting. This first dimension of Mindful parenting combines listening and mindfulness. By paying full attention to their children, parents signal that they are really listening to their children.

b. Acceptance of not judging yourself and your child

Rogers (in Bernard, 2013, p. 9) states that self-acceptance by parents will be able to increase their ability to build relationships with their children. Parents who have selfacceptance and their children will be aware of appreciating the positive character that exists in themselves and their children. In addition, parents will be able to respond to negative events by remaining proud to accept themselves and their children unconditionally. The conditions that affect one's self-acceptance, according to Hurlock (in Bernard, 2013) are self-understanding, realistic expectations, free from social barriers, pleasant social behavior, stable self-concept, pleasant emotional conditions, memories of success, identification. with people who have good self-adjustment, selfperspective, childhood parenting, and a stable self-concept.

c. Emotional awareness of yourself and children

Emotional intelligence is an individual's ability to recognize his own feelings and feelings of others, motivate himself and manage emotions well in himself and in relationships with others (Goleman, 2001). Emotionally intelligent parents are parents who are able to understand every feeling that arises in them from every experience, and are not easily influenced by them. The main indicators of parents who have the ability to recognize their own emotions are knowing the emotions that are being experienced and being able to use the emotions they are experiencing to make the right decisions and actions (Goleman, 2006). Parents who are able to regulate their emotions properly will be able to position themselves to decide whether to act or act in any condition anywhere. This means that parents who have emotional maturity can still behave in a certain way that does not harm or make children uncomfortable with their existence.

Besides, parents must stop spreading communication viruses, namely:

1. Governing

2. Blame

3. Underestimating

4. Comparing

5. Threatening

6. Stamp / label

7. Lied

8. Entertaining 


\section{Criticizing}

\section{Satire}

11. Analyze

\section{Leverage}

Several points in implementing positive parenting are parents working together between father and mother (partnership parenting). Parents must learn to work together well, especially in teaching the values of life to children. There should be no disagreements in teaching discipline and the norms of life. Thus, children will obey parental guidance because they see that both their father and mother agree to share the same view. So fathers are also involved in parenting not only mothers.

In addition, parents must also realize that each child is unique and can develop according to their respective ages. Our job as parents is to always encourage children to develop and don't forget to keep giving rewards to children. The easiest rewards parents give are touch and praise which will encourage the child and make the self-concept more positive.

\section{Conclusion}

The activities carried out by PAUD Al-Ummah Deli Tua have several conclusions, namely:

1. Parents have an understanding of positive parenting and how to apply it in the family

2. Parents have more insight into how to communicate and behave so that parenting can have a positive impact on children

3. Parents' knowledge increased after attending this counseling.

Hopefully through this activity, in the future we can provide other parenting counseling so that it can provide insight, especially in the psychological development of children.

\section{References}

Amini, Mukti. (2008). Pengasuhan Ayah Ibu yang Patut, Kunci Sukses Mengembangkan Karakter Anak, Yogkarta: Tiara Wacana

Astuti, W. W., et al (2019). Indication of Moral Erosion in Children's Fiction. Britain International of Linguistics, Arts andEducation(BIoLAE)Journal, 42-50.

Bluth, K. \& Wahler, R.G. (2011). Parenting Preschoolers: Can Mindfulness Help? Department of Psychology, Child and Family Studies, University of Tennessee. doi: 10.1007/s12671-011-0071-4.

Duncan, dkk. (2015). Can Mindful parenting be Observed? Relations between Observational Ratings of Mother-Youth Interactions and Mothers ${ }^{\text {ee }}$ Self-Report of Mindful Parenting, Journal of Family Psychology, 29 (2), 276 -282.

Febrianti, N. D., Yus, A., Yusnadi. (2020). Identification of the Parent Activity in helping the development of social skills - Emotional children ages 5-6 Years in Kindergarten Independent Islamic, Percut Sei Tuan, Medan Deli Serdang Regency. TA. 20182019. Budapest International Research and Critics in Linguistics and Education (BirLE) Journal, 1094-1098.

Hurlock. Elizabeth B (2014). Perkembangan Anak, Terjemahan Meitasari Tjandrasa. Jakarta : Erlangga.

Mulyasa. (2012). Manajemen PAUD. Bandung: PT. Remaja Rosdakarya 
Novita, Erliyanti, (2012), Perbedaan Agresivitas Ditinjau dari Pola Asuh Orang Tua, Analitika: 4 (2): 53-56

Sanders. (2011). Development, Evaluation, and Multinational Dissemination of the Triple P Positive Parenting Program, Annual Review of Clinical Psychology. Doi: 10.1146/annurev-clinpsy-032511-143104.

Smith. (2002). Parent Education, dalam Bornstein (Penyunting), Handbook of parenting volume 4, 389-444. New Jersey: Lawrence Erlbaum Associates, Publishers.

Sugiharto. (2020). Geographical students' learning outcomes on basic political science by using cooperative learning model with Group Investigation (GI) type in State University of Medan, Indonesia. Journal of Human Behavior in the Social Environment, 447-456.

Suharyanto, Agung. (2015). Pendidikan dan Proses Pembudayaan dalam Keluarga, JUPIIS: Jurnal Pendidikan Ilmu-Ilmu Sosial, 7 (2) : 162-165.

https://hellosehat.com/parenting/tips-parenting/pengasuhan-positif-parenting/\#gref)

https://sahabatkeluarga.kemdikbud.go.id/laman/uploads/Dokumen/3995_20160824/Buku $\% 20$ Saku\%20Pengasuhan\%20Positif-edLina.pdf 